\title{
Goodbye on the Seas: Rising Waters, Submerging Lives
}

\author{
Christina Yin
}

https://orcid.org/0000-0002-0800-049X

Swinburne University of Technology, Sarawak

\begin{abstract}
This hybrid memoir begins and ends with a sea journey. Combining real-life story and dystopian imaginary, the author takes us to the Straits of Malacca off the coast of Peninsular Malaysia, to futures of submerged cities in 2050, and on a final journey into the South China Sea off the island of Borneo. This is a story of climate change and rising seas entwining tropical vignettes of pandemic lockdown, of a father's dying, and the author's future life submerged. It questions human survival in a world of demise, shaped by pandemic and surrounded by waters slowly but inexorably rising.
\end{abstract}

Keywords: sea level rise, submerged cities, climate change, dystopian imaginary, hybrid memoir, speculative fiction, pandemic, Malaysia, Borneo

eTropic: electronic journal of studies in the tropics publishes new research from arts, humanities, social sciences and allied fields on the variety and interrelatedness of nature, culture, and society in the tropics. Published by James Cook University, a leading research institution on critical issues facing the world's Tropics. Free open access, Scopus Listed, Scimago Q1. Indexed in: Google Scholar, DOAJ, Crossref, Ulrich's, SHERPA/RoMEO, Pandora. ISSN 1448-2940. Creative Commons CC BY 4.0 free to download, save and reproduce. To cite, include: Author(s), Title of Paper, Editors (Eds.) Special Issue Title (Special Issue) eTropic, volume, issue, year, pages and DOI: http://dx.doi.org/10.25120/etropic.20.2.2021.3818 
eTropic 20.2 (2021) Special Issue: Tropical Imaginaries and Climate Crisis

\section{Goodbye on the Seas}

$\mathrm{T}$

The seas became quiet at the start of the pandemic in March 2020. From luxury cruise liners to tiny fishing boats and great cargo ships transporting goods from one part of the world to the other, vessels were grounded or stranded offshore. Since then, vaccinated or not, captains and their crews have resumed their work on the seas; they must, for it is essential. Some ninety percent of the world's goods are transported on water and the business of supply and demand has not allowed the coronavirus to bring this supply chain to a halt. But while our lives have been changed immeasurably and the human species fights to contain and render the virus harmless, trying to bring back some semblance of (new) normal, we are unable to halt an even more pressing catastrophe.

The seas on which these ships travel are rising. It is predicted that in 2050, Kuching, the capital city of Sarawak on Borneo will be an island metropolis, while other cities and towns on Peninsular Malaysia will be totally submerged: Alor Setar, Kuala Selangor, Muar, Pekan and Teluk Intan. Of course, there are the climate change naysayers just as there are the anti-vaxxers, but the science tells us that human activities such as burning fossil fuels have trapped heat in the earth's atmosphere, causing global warming. This heat results in the glaciers and ice sheets in Antarctica and Greenland melting and not being replenished in the increasingly warmer winters. Eventually, it is predicted that even the Arctic will be ice-free in the summer. All those great chunks of ice melting and staying melted means that the sea water levels will rise and many islands and coastal areas will disappear beneath the water. The Tropics is predicted to be one of the most severely affected regions of sea level rise. This is where Malaysia lies: its peninsula being the southern-most tip of continental Asia where it adjoins Singapore via a causeway constructed to facilitate commerce and travel to and from the island nation, while its eastern states share the megadiverse island of Borneo with Brunei and Indonesia.

Along with the warmer Earth and the disappearance of land beneath the seas will come a proliferation of diseases. Human actions may or may not have sparked the $21^{\text {st }}$ century coronavirus pandemic, but it seems clear that we will be to blame for the rise in cases of dengue, malaria and cholera resulting from global warming, rising sea levels and subsequent flooding of sewers and poor sanitation.

But it is not these diseases that trouble me on this day. The Earth is bathed in the morning sun when we park the car and take a ticket from the booth. We are all masked, but I am not thinking of the coronavirus either. Later, I will think about Pangkor and Langkawi Islands where my father took us for holidays when we were children. Those islands may one day be submerged, just as this port we are entering, once known in 
eTropic 20.2 (2021) Special Issue: Tropical Imaginaries and Climate Crisis

colonial times as Port Swettenham, may, too, no longer exist. But none of this is on my mind on the $14^{\text {th }}$ July 2020 .

\section{The Straits of Malacca}

We are seven people on a small chartered boat chugging out of what is now called Port Klang, some 25 kilometres from Damansara Jaya where my father had lived the past 40 years. Although this is one of the busiest container ports in the world, on this morning there is little movement on shore and hardly any disturbance on the water. A few cargo vessels and fishing boats sway to the gentle ripples our boat makes as we set out to sea on the Straits of Malacca as if towards the whitish grey clouds scattered across the sky, but which can never be reached.

The engine is loud in my ears. I see the water swirling, the jetty we've left and the wooden floorboards and slats and simple plastic covers of the seats in the chartered boat. I am thinking, but not thinking. This is an unthinkable, unbelievable journey. It has come to this so quickly. This final journey for my father has come too soon. Just two days ago, as I held his swollen, heavy hands, he had whispered to me hoarsely, "Stay with me." Those were his last words. He could speak no more as he struggled to breathe, a loud regular gasping was all we could hear. Later, I read about agonal breathing. But that was much later.

With us on this journey are the boatman and two men from the funeral services. They have probably made this trip many times and have witnessed many families taking the final journey with their loved ones. Maybe they are by now unaffected by the different displays of grief. Maybe not. But that is another thing that I don't think about till much later.

We sit in the cabin, masked. Katie and Yoshua are each holding a sheet of paper, messages to my father to follow him into the water. Later, Yoshua will hold his phone up to livestream the goodbye for Emily who is far away, alone, at the University of lowa. For now, we just chug along.

When the engine stops and the boat is rocking gently, silently, on the waters, we get up and go on deck. Damian, the funeral director, comes over to me with the urn. It is large and white and smooth with no handles, and that worries me. Damian explains that the urn contains my father's ashes and that the solid bit at the top is part of his skull. This is what I am hearing. Then he tells me where to go and we step out over to the rail to the furthermost edge of the boat's bow. 
eTropic 20.2 (2021) Special Issue: Tropical Imaginaries and Climate Crisis

Yesterday, my brother had spoken at the crematorium to the few mourners who had been allowed to say farewell personally to my father. These were the strange adapted rituals in the time of COVID-19 restrictions. My mother hadn't wanted to speak at the crematorium and she also hadn't wanted to cast my father's ashes into the sea. It is just as well. It would have been difficult for her to bend over the edge of the boat and empty the urn. As the boat rocks I worry I might drop the urn. It is heavy and I have to grip it at the top. When it has been emptied it into the sea, I hand the urn back to Damian who washes it out with water, shaking it out over the waters. My husband Melvin helps wash my hands over the boat's edge with disinfectant we had brought to stay safe.

I take flowers from the wreathes that had been sent to the house and throw them into the water after the ashes. My mother, brother, sister-in-law, husband and daughter Katie join me. Soon, the carnations and ferns bob and float on the water; the paper carrying messages to my father gently sink beneath the greenish white-flecked waters and I guess, my father's remains. So quickly, a life of 81 years lived on this earth expires, is cremated and scattered in the Straits of Malacca four days later. And we had waited an extra day for my husband Melvin to fly in from Kuching, Sarawak, to be with us for my father's final journey.

This could have happened the day after my father passed away. How can it happen so quickly? Why should it? Why do we hurry to dispose of the remains of our loved ones? And rush to go through their belongings and take care of the things that concerned them when they were alive? The mobile phone, the credit cards, the bills, the less important things like shopping centre cards... These things once mattered. I want to call my father back, to tell him that I did care, that I do care, that I can't bear to read the emails and the text messages, the groups he once belonged to - the Ipoh Squash group, the Geological Survey group, Good Smoke Friday, Ipoh Mates, - but now no more. His friends have moved on and so they must. They were sad and for a few intense days they talked about my father, reminisced, gave me their memories of him so we could create a video about him, with their words. And then, somehow, they have all moved on.

We throw the last of the flowers and ferns into the sea. Yoshua videos it all for Emily in lowa City, where later, she will place a rose at the Dancer's Garden where she hopes my father will watch her when she goes for classes and practice. She could not come home because of the chaos in international travel, cancelled flights, passengers stranded in obscure airports and the unfathomable behaviour of Americans who refuse to wear masks. Their rights trump the science. 
eTropic 20.2 (2021) Special Issue: Tropical Imaginaries and Climate Crisis

The boatman turns the boat around and we head back to shore. So quickly this ceremony is over. There are no other rituals for us. Just the cleaning up of a life lived for 81 years. When I am 81 years old it will be 2046. According to respected scientists, four years after that, Port Klang will be completely submerged. This place that started out as a colonial outpost, a malaria infested swamp, once the eleventh busiest container port in the world, will be no more than a ghostly underwater thing of the past; visited only by underwater explorers.

According to the Malaysian-based research Centre for Governance and Political Studies, by 2050 nine of Malaysia's 13 states will be severely affected by rising sea levels. Malaysia is situated on a peninsular south of Thailand as well as comprising two states - Sarawak and Sabah - across the South China Sea on the island of Borneo. It is predicted that the state of Kedah will have many more islands in addition to the existing 99 in the Langkawi archipelago in the Straits of Malacca. As it is today, five these islands are only visible during low tide. The country is surrounded by water; global warming and rising sea levels should concern us. Yet, other than a few articles in 2019, no one seems overtly concerned.

When I think about the sea levels rising, I think about my father. He loved the ocean and he loved swimming. When my brother and I were little, he would take us for beach holidays: to Pangkor Island off Lumut in Perak; and Langkawi Island, the Jewel of Kedah. My mother had never learned to swim, but she loved to bounce along in the shallow waters where gentle waves would nudge her as she watched us snorkelling.

When my own children were growing up, my father started it again, taking us all to Pangkor Island during the school holidays at the end of the year. It hadn't mattered that this had been when the monsoon rains were scheduled; we were on the west coast, shielded from the worst of the deluge. I wonder how he would feel, knowing that the islands we once enjoyed might be gone forever; that we would be pushed further inland, higher up to the mountains, along with the newly delineated paddy fields, the transplanted 'rice bowl of Malaysia', in order to escape the hungry relentless saline waters that we had brought upon ourselves.

My father is gone and he will not see this. He had been through a battery of tests but there had been no diagnosis. Nothing could be concluded, but soon it became evident that eating was becoming a serious issue. That which comes naturally to all living things now had become anathema to him. He had been eating less and less, even his favourite rice porridge with salted fish and peanuts could not entice his appetite. At Chinese New Year in February 2020, the first year of the pandemic, he was still well enough to enjoy small portions of the delicacies Mum cooked. He still drank the tea at the Chinese tea ceremony on the first day and ate the traditional vegetarian breakfast. 
eTropic 20.2 (2021) Special Issue: Tropical Imaginaries and Climate Crisis

But after Melvin and I had left to return to our home in Kuching, things grew worse. As the virus spread through the country and the government struggled to control our movements to contain it, my father was struggling with his own body. Cancerous cells that had invaded him were taking control, consuming him and rendering him so weak that he could no longer stand by himself, let alone walk.

In June, when inter-state travel was finally allowed again, Melvin and I took the first flight we could from Kuching back across the South China Sea to Kuala Lumpur. Wearing masks and face shields, equipped with hand sanitisers and wet wipes to clean the seats, arm rests and table tops, we sat stiffly through the one hour, forty minute flight across the waters. In the past, taking a flight had always meant the start of a new, exciting adventure. Now, I felt I was in a capsule, trapped with an invisible contagion lurking, waiting to pounce on random, hapless victims.

Arriving at Kuala Lumpur International Airport, we were met by Katie, our elder daughter who, having flown back from Glasgow where she was studying, had just emerged from a two-week quarantine in a hotel. Katie updated us on the drive from the airport just as my mother and my brother had over text messages, voice and video calls - my father was eating morsels and drinking little water or protein mixes; he was aching all over, needing constant massages to ease the pain. My brother had told my father to hold on, that I was on the way.

When I finally saw him - in the small room on the ground floor where he had taken himself after the stairs had become too difficult to manage - my father had transformed. His body which had enjoyed rugby, swimming, squash and golf, along with jungle treks mapping the geology of the new Malaysia, was failing him. When he agreed to go to the hospital, I knew it could only be because the pain was too terrible. He had always been the worst patient, refusing to visit doctors and preferring to selfmedicate. Now he had to admit that his body would not heal on its own.

Eventually Melvin had to return Kuching to work - which more and more people were grateful to have - but my father and I still had six weeks together. I slept on the floor outside the room we had fashioned for him on the ground floor of the modest terrace house he had moved to from Ipoh all those years ago filled with vigour and hope. Now ensued dark, desperate days. I compartmentalised myself: my father; my mother; Katie who was helping in between studying, watching videos of veterinarian sciences beamed from Glasgow; my teaching; my marking; my doctoral thesis; my husband Melvin in Kuching; our daughter Emily so far away from us all, alone in a Republican State in a country where thousands were suffering and dying every day. 
eTropic 20.2 (2021) Special Issue: Tropical Imaginaries and Climate Crisis

In and out of the Accident and Emergency ward, until eventually, my father was admitted to the University Hospital's oncology ward. He was hardly eating and could not stand without help. A week before, when Melvin was still here, and my father was still at home, we had propped him up and helped him to walk a few steps from the downstairs bedroom to the dining table where he could sit in the natural daylight. It had been a triumph. Now, it was impossible. Tests, brain scans, dialysis, teeth pulled in preparation for chemotherapy that did not take place because he never grew strong enough. Medication, pain killers, hallucinations, anything for some respite - but it never came. Yet when we sat with the whole team of specialists, we were told he could recover.

Trying to understand and to grasp what was happening, I asked directly: "on a scale of 1 to 10 with 10 being the best of health, what is my father's condition?" The specialist said my father rated at 5 or 6 , so we had hope. They asked about a live-in nurse to help at home, telling us that we should have someone to take care of his basic needs so that we could spend quality time with him. So, we prepared for a live-in nurse through an agency, bought a wheelchair and a ramp for the split-level steps in the house, put in an air-conditioner and got a handyman to put up a curtain to close off the room we had converted on the ground floor.

Each day we were allowed to visit him at the oncology ward, one at a time: we talked to him through masks, we brought him food he hardly ate. With each passing day, he grew weaker and spoke less. When he did speak, he asked what we had eaten that day, if the banking had been done. Even then, he wanted to know we were all right, taken care of. But when asked about himself, he either withdrew into an angry silence or just closed his eyes, not wanting to talk, not wanting to be forced to eat or drink.

Once, when I was coaxing him to eat the food Mum had prepared and I had brought to the hospital, he whispered "Will it help?" I could not answer him straight away. It was a valid question; his condition was so terrible. Would it help if he forced himself to eat though his body told him not to? The doctors had put a feeding tube in for a few days, but in the end, they had taken it out because it could not continue indefinitely; he needed to eat on his own.

Then, strangely, we were told he could go home, and that we should bring him back to the hospital the next week for a follow-up check with the oncologist. We thought this was the start of a long treatment and convalescence, but it was an appointment he did not keep. 
eTropic 20.2 (2021) Special Issue: Tropical Imaginaries and Climate Crisis

I know now that they knew he was dying, but the doctors and nurses couldn't or didn't want to tell us the truth. Those six weeks I had been watching my father die, but I had not known it. They had told us he had two years. He did not have two months.

My father came home in an ambulance while I was busy upstairs teaching online. When I came downstairs, he was there in the room we had prepared for him. He did not like the nurse we had employed. When she tried to help him, he growled, "Leave me alone." He could still get angry. So many things had been taken from him: his ability to clean himself, to walk, to feed himself, to take care of himself, to maintain his privacy and his dignity. All those years he had taken care of us, and now he was so reduced, diminished.

Yet by the afternoon, he could no longer keep the nurse from bothering him. My mother had asked her to shave him. Instead of just shaving his jaw and the wisps on his upper lip, the nurse shaved all that as well as what little he had left on his entire head. My father could offer no resistance. His eyes were wide open and his mouth gasping for breath.

After dinner that evening I went to sit with him. I held his heavy swollen hands and he breathed out, "Stay with me." I stayed with my father for as long as I could. He never spoke to me again. There was just the rasping agonal breathing, his eyes wide open, as he struggled to breathe air into his lungs. I stayed with him until 3 a.m. It was Saturday and I did not have to teach, but I knew I had to sleep at least a little to be able to function when the sun rose. So, I left him with the nurse. Just three hours later, I came downstairs to the little room. I had set my alarm to wake early before anyone else so I could spend some more quiet time with my father.

The nurse told me he hadn't slept at all. I told her to get some sleep and then I took his hands again and sat with him. His eyes were still wide open and his breathing as loud and rasping. My brother had told me that his father-in-law had had the same loud breathing but recovered. So, I thought I had more time. When the others woke, I left my father's side. We ate breakfast and the busyness of life started again; I thought it was safe to leave him.

And it was true that after breakfast, sometime between washing the dishes and doing the laundry, my father's loud gasps had stopped. He was breathing normally, and I thought what my brother had said was happening now. Our father would get better.

Just a few hours later - after trips to the self-service laundromat to use the dryers, after lunch and washing up, with Katie studying up in her room, Mum resting in the living room, my brother waiting for a call - I had settled down with my laptop to work 
eTropic 20.2 (2021) Special Issue: Tropical Imaginaries and Climate Crisis

at the dining table near my father. The nurse walked up to me and asked me to come over to the little room.

My father had gone. I hadn't stayed right there with him. I had thought I had more time. I had work to do, and I thought I would have time to hold his hands again. But he didn't have time; he had had to go.

Maybe that is what is happening now. The pandemic continues to rage. It will never leave us as long as there are pockets in the world where people cannot be vaccinated or where new variants have taken hold. While we're busy with other things, the Earth really is warming, the polar ice caps are melting and the seas are rising. We are fighting a losing battle as the waves lap on our shores - over reclaimed land, slowly eroding our river banks, filling the monsoon drains, pushing us further inland to higher lands. I see this happening when I remember holding my father's hands on his last night with us on this desperate, despoiled Earth. How foolish I was to think he would recover when he gasped for every breath, when he asked me to stay with him, something unheard of just days earlier. Now, we have heard the scientists speak and we acknowledge the things that are happening with the relentless rising waters, yet we blithely carry on. While entire populations of island nations are negotiating with Australia and New Zealand for a new home once their lands are submerged, other people buy land and build seafront homes near Auckland. They have a beautiful view - for now.

I am waiting to go to the places we enjoyed with my father. One of them was a Japanese bookstore at the Kuala Lumpur Convention Centre, at the base of the worldrenowned Petronas Twin Towers. A visit to that bookstore was a fun outing to the city. But perhaps it will no longer be housed at the KLCC. In 2050, the Petronas Twin Towers will likely no longer be among the tallest buildings in the world, for its lower floors will be submerged. Engineers will have converted the other floors and built an underground tunnel leading to the light rail transit that will operate safely underwater connecting to communities on higher ground. Other landmarks such as the law courts complex, the neo-Saracenic Kuala Lumpur Railway Station, and the Dataran Merdeka (Independence Square), may share that underwater world.

The Indonesian capital Jakarta is already sinking and like other major cities in Southeast Asia, is expected to be underwater by 2050, so the capital of that vast archipelago is being moved to Kalimantan on the island of Borneo. We will be neighbours, but perhaps only for a little while, because Kuching, the capital of Sarawak is a riverside city and the predictions are that by 2050 , it too, will be heavily submerged. Perhaps the new Indonesian capital will also be submerging. 
eTropic 20.2 (2021) Special Issue: Tropical Imaginaries and Climate Crisis

In these watery landscapes where will the semi-wild orang-utans at Semenggoh Wildlife Centre go? And their wild cousins along the Batang Ai river? The sun bears and the monitor lizards? The proboscis monkeys and the mousedeer? When vast areas of Sarawak's lands were flooded to build the dams in the 1980s and 1990s, humans had rescued the wildlife stranded on islands in the middle of the artificially constructed lakes. Today, we cannot rescue ourselves, much less the iconic wildlife that make us one of the most biologically diverse countries in the world.

Though we scattered his ashes and bits of his skull in the Straits of Malacca, my father stays with me now. At times his image fades, but like a Hogwarts headmaster in a picture frame, he comes back. Sometimes, I ask him questions, but he's mostly quiet. I wonder about many things, but most of all I would like to talk to him about the rising seas and the lands that will be left. My father studied and knew the geology of this country like few others. He was among the first Malaysians to head the Geological Survey; his name is on many maps and he knew our lands and their natures intimately. I wonder what he would have made of the changes that are taking place now. But my father doesn't give me any answers directly. I think he is telling me that there are no simple answers and that I will have to figure out what to do myself.

So, in return, I will tell him this story. It is the story of a future I might have lived. If I hadn't married. If I hadn't had two children. It is the story of someone who lives in this world that the pandemic has shaped. It's a story of the water that was once a refuge, but which now threatens us because we have destroyed the balance that nature had shaped so beautifully. This is the story of a person who lives alone in a world with no way out of a pandemic and no way to escape the rising seas; she has one choice left and she takes it while the sea is still warm and friendly and full of good memories of holidays and swimming, and of her father in his prime.

\section{The South China Sea}

My dog kicks her legs as she sleeps. Maybe she is dreaming of chasing the neighbour's cat. Maybe she is hunting that elusive mouse that has been nibbling on fruit peel and vegetable waste in the compost heap. Or maybe she is paddling in the shallow waters of Pasir Pandak. The dog is old, with white hairs on her muzzle and some on her hind legs, but when she had been young, working as a team with her sister, she had been a formidable hunter and an intrepid swimmer.

I bend and pat her head, gently stroking her long soft ears. I won't be able to take her with me. That is the one thing I'm sorry about. Leaving would not be a problem if it weren't for my old dog. She would love the car ride, her nose sticking out, the wind 
eTropic 20.2 (2021) Special Issue: Tropical Imaginaries and Climate Crisis

blowing her long ears back. But I cannot leave her in the car when I reach the beach and I cannot take her with me into the sea.

And there is no way to explain to the police if I were stopped at a roadblock. This is not the time to take a dog for a joyride. So, I sit with my old dog a long while, stroking her soft head and ears, remembering the good times we'd had when we had both been young and strong. My mother had told me years ago that growing old is terrible. I will add to that. Growing old alone in a never-ending pandemic that has persisted for half a century when climate change is causing sea levels to rise is abominable - is intolerable.

If I spoke to her, my sister would tell me my thoughts were nonsense and that I should stop brooding, but I know my departure will take one more thing off her mind. She will no longer have to worry about me. And this is important since sustaining life in this pandemic-ridden water world is no easy task. She has her children and her husband, and she will look after my old dog.

I will not let my old dog struggle and kick, trying to follow me out to the South China Sea and it is this thought that propels me up and away, giving her a final pat. I pick up the car keys and quietly open the gate. She looks up at me and then settles down again. She knows my routine and thinks I will be back after picking up groceries. I look at her one last time. I never thought I would ever leave her behind, but I know my sister and her husband and children love the old dog.

My trusty Kembara is a dream. I love to feel the engine purring as I shift gears, making it all the way to fifth for the first time in so long. Never once, even at the traffic lights, do I see a police car or motorcycle. It is as if the police are like the rest of the population in this perpetual lockdown, staying home.

It is July 2051 and every month, the restrictions are extended. There is no end to this dystopian reality. New variants emerge and claim more victims, faster than any scientist or pharmaceutical company can unravel viral genetic codes and produce new vaccines. Countries that have released their populations from quarantine conditions quickly learn to regret their hasty decisions and have implemented stricter lockdowns. The police worldwide are militarized; inter-district, inter-state and international borders are closed.

But here I am, driving freely alone on the road, coasting along, singing to Peter, Paul and Mary, to Simon and Garfunkel, John Lennon, Joni Mitchell and Bob Dylan at the top of my lungs, with the windows down and my hair really blowing in the wind, all the way to Damai. How I have missed driving on the long road trips with my parents and 
eTropic 20.2 (2021) Special Issue: Tropical Imaginaries and Climate Crisis

sister during the school holidays. Those had really been the days! Once we had driven all the way to the neighbouring state of Sabah and had visited the 130 million-year-old Danum Valley rainforest and gone island hopping in the Coral Sea off the coast of Borneo. Of course, that had been when I was little, before the Sulu pirates had started kidnapping people and before the islands had all submerged. But since COVID-19, life has been a misery. Everything and everyone is online. This is a real virtual reality that I cannot adapt to. I'm not the only one. A lot of people have found a way out, but those ways are not for me.

I find a spot to park the Kembara, a little out of the way where it cannot be easily seen, and walk slowly to the beach, enjoying the crunch of the sand and pebbles beneath my feet and the earthy smell of the trees and shrubs around me. The sea is calm, and the rush of the waves meeting the shore is like a balm to my tired body and soul. I sit under a tree, just watching and listening to the rhythm of the waves, breathing in the sea air. Once I see a little splash and dip about a hundred meters out. Maybe it is an otter or even a dolphin! I strain my eyes to see it again, but the waters are calm. Up above, the sun is relentless, but I think I see a pied hornbill and a raptor, a species I cannot recognize.

When the sun has peaked overhead and it is the hottest part of the day, I take off my jeans and t-shirt, stripping to my swimsuit. Then I step into the water. The waves are gentle and the water is warm, just like how I remember. When the water is waist high, I push off with my toes from the sandy sea bed. We never forget how to swim, and I, a school swimmer, know I can keep up the rhythm of arms and legs and breathing for hours. For this reason, I could not have brought the old dog. She would have struggled to keep up and it would have been agonizing to witness. I had watched too many relatives and friends struggling. I won't watch my old dog struggle and I know I won't struggle. With long smooth strokes, I reach out to the horizon where the sea never meets the sky. I am swimming in the South China Sea which is slowly rising in a world that will never be the same. It's not a world I belong in, so I will find my way in the rising seas. 


\section{Acknowledgments}

This piece is dedicated to my father, Yin Ee Heng.

Dr Christina Yin is a former news anchor, journalist, columnist and media executive at an international conservation organisation. Currently, Christina is a writer and senior lecturer at Swinburne University of Technology, Sarawak Campus. Her PhD on "Creative Nonfiction: True Stories of People involved in Fifty years of Orang-utan conservation in Sarawak" was the first in Creative Writing at the University of Nottingham Malaysia. Christina's fiction and nonfiction writings have appeared in Anak Sastra, eTropic, New Writing and TEXT, among others. 